\title{
The Combination Of Boiled Katuk And Kelor Leaves Towards Breast Milk Launch
}

\author{
Weni Tri Purnani, Meirna Eka \\ Fitriasnani, Huda Rohmawati, \\ Dewi Nur Afifi \\ Faculty of Health Sciences of \\ Kadiri University, Kediri \\ Email: \\ wenitripurnani@unik-kediri.ac.id
}

Received: October 5, 2020

Accepted : November 27, 2020

Published : November 30, 2020

\section{ABSTRACT}

The launch of breast milk on postpartum mothers should be treated appropriately to make the exclusive breast milk work smoothly. The survey result in Gampengrejo's community health center in April 2019 was obtained 9 out of 14 postpartum mothers $(64.28 \%)$ experiencing breast milk flow problems. Postpartum mothers consuming boiled katuk and kelor leaves can smooth the flow of breast milk. Many problems have been spent on the post-partum mothers on day 1 up to day 7. The purpose of this study is to determine the influence of the combination of boiled katuk and kelor leaf.

The design of the research used is an experimental study with a pre-experimental design using pre-test and post-test design. The population is the mother of the postpartum on day 1 through day 7 in Gampengrejo's community health center Kediri. The sampling technique uses a simple random sampling technique and it is obtained 16 samples. The samples are given the treatment of a combination of boiled katuk and kelor leaves. The research instrument used is an observation sheet. Research results were analyzed using the Wilcoxon test.

Based on the result, it shows almost all respondents breast milk that was 13 people (81.3) come out smoothly after being administered a combination of boiled katuk and kelor leaf. Based on the results of the analysis obtained $\rho$ value $0.000<0.05$ indicating the influence of the breast milk flow between before and after administering the combination of boiled katuk and kelor leaf. The medical staff is expected to provide information about the benefits of the combination of boiled katuk and kelor leaf for the postpartum mothers.

Keywords: Katuk leaf, Kelor leaf, Breast milk flow, Postpartum mother

Copyright (C) 2020 IIK STRADA Indonesia All right reserved.

This is an open-acces article distributed under the terms of the Creative Commons Attribution-ShareAlike 4.0 International License.

\section{BACKGROUND}

The World Health Organization (WHO) and the United Nation Childrens Fund (UNICEF) recommend that children only be given breast milk for at least six months in the life of a baby and continue with proper companion meals up to the age of 2 years in order to lower the child's morbidity and mortality rate (Yusrina \& Devy, 2016).

The exclusive breastfeeding range for infants under six months in Indonesia has generally increased in recent years. However, the coverage is only a false achievement. Indonesia's health 
profile data shows that the number of exclusive breast milk for infants less than six months old reach up to $52 \%$ (Indonesian health profile, 2018). Despite its increasing for $11 \%$ higher than in 2012, this achievement meets a minimum target of $50 \%$ set in the last five-year of the national development plan. However, the same data source also shows that the percentage of this exclusive breast milk decreases as the child ages. For children under one month, the percentage is $67 \%$. This number is reduced by up to $55 \%$ in children aged 2-3 months and decreasing again, only $38 \%$ in children aged 45 months. It means the exclusive breast milk number at $52 \%$ is a false achievement because it has not described the percentage of babies who gained breast milk for the first six months of his life, without other intakes such as formula milk (factory-made milk substitute), banana, tajin water.

October to December 2019 in Kediri, there are 163 postpartum mothers. In the working area of Gampengrejo community health center in December, there is 34 postpartum mother. From the interview on 14 postpartum mothers, there are 9 (64.28\%) mothers who are experiencing issues of breast milk flow, and $5(35.72 \%)$ postpartum mothers do not experience breast milk flow problems. Based on the data, there is still a problem of the breast milk flow that is relatively high in the working area of Gampingrejo community health center in 2019.

The unyielding of breast milk can be caused by some factors, both physical and psychological. Mental factors heavily influence breast milk production because the feeling of a mother can inhibit or increase the expenditure of oxytocin, when the mother in distress, sadness, lack of confidence, and various forms of emotional tension can decrease the production of breast milk (Fahra, 2017).

Some factors affecting the expenditure of breast milk are social-cultural change, psychological factors, increased promotion of infant formula milk, mother food, use of contraceptives. A solution that can be used to overcome the flow of breast milk is by consuming a combination of katuk leaves and kelor leaves.

Katuk (Saouropus Androgynus), One of the benefits of Katuk leaves is to launch the production of breast milk because it contains seskuiterna compounds. Besides launching breast milk, Katuk leaves also have several benefits, such as Frambusia, constipation, ulcers, and as a natural dye. The alkaloid content and sterol of the katuk leaves can increase the production of breast milk to more because it can increase glucose metabolism for lactose synthesis so that the production of breast milk increases (Rahmanisa \& Aulianova, 2016) Kelor plant (Moringa oleifera) is one kind of tropical plant that quickly grows in tropical areas such as Indonesia. The Kelor plant is a perdu plant with a height of 7-11 meters and thrives from lowland to a height of $700 \mathrm{~m}$ above sea level. In Indonesia, the Kelor plant is a local food ingredient that has the potential to be developed in culinary nursing mothers, because it contains phytosterols compounds that function to improve and perform the production of breast milk (Lacagocyum effect)(Septadina \& Murti, 2018). This study aimed to know the influence of the combination of katuk and kelor leaves towards the flow of breast milk of postpartum mothers.

\section{METHODS}

This type of research is experimental with pre-experimental design by using pre test-post test design. The sample in the study is the postpartum mother day 1-7 without complications, giving the exclusive breast milk, do not use hormonal contraceptives, do not consume milk stimulating drug. The sample is taken using simple random sampling technique and it obtains 16 respondents. The research was conducted at Gampengrejo community health center in Kediri in January 2020. Assessment and observation of respondents about the breast milk flow from mother to baby's mouth is assessed based on a questionnaire instrument. It consists of favorable and unfavorable questions. The result of the assessment is categorized into two: smooth and not smooth. Analysis of this research data uses Wilcoxon statistical test.

\section{RESULTS}

Respondents' Characteristics

Table 1 Frequency Distribution Of Respondents Characteristics Based On Maternal Age

\begin{tabular}{lll}
\hline Mother's Age & Total & Percent $(\%)$ \\
\hline$<20$ years & 1 & 6,3 \\
$20-35$ years & 13 & 81, \\
$>35$ years & 2 & 12,5 \\
\hline
\end{tabular}




\begin{tabular}{lll}
\hline Total & 16 & 100 \\
\hline
\end{tabular}

Source: Research Primary Data in 2020

Based on table 1, it can be interpretated that the age of almost all respondents $13(81.3 \%)$ are 20-35 years.

Table 2 Frequency Distribution Characteristics Of Respondents Based On The Occupancy

\begin{tabular}{lll}
\hline Pendidikan & Total & Percent $(\%)$ \\
\hline IRT & 11 & 68,8 \\
Wiraswasta & 5 & 31,3 \\
PNS & - & - \\
\hline Total & 16 & 100 \\
\hline
\end{tabular}

Source: Research Primary Data in 2020

Based on table 2, it can be inferred that the job of the most respondents $11(68.8 \%)$ are housewives.

Table 3 Frequency Distribution Of Respondents Characteristics Based On Education

\begin{tabular}{lll}
\hline Education & Total & Percent $(\%)$ \\
\hline Elementary Sch & 1 & 6,3 \\
Junior High Sch & 5 & 31,3 \\
Senior High Sch & 6 & 37,5 \\
University & 4 & 25,0 \\
\hline Total & 16 & 100
\end{tabular}

Source: Research Primary Data in 2020

According to table 3, the interpretation of the characteristics of respondents based on education which is nearly half of respondents $6(37.5 \%)$ is high school graduates.

Table 4. Respondent Frequency Distribution Based On Parity

\begin{tabular}{lll}
\hline Breast Feeding Freq. & Total & Percent $(\%)$ \\
\hline Primipara & 6 & 37,5 \\
Multipara & 10 & 62,5 \\
Grand multipara & - & - \\
\hline Total & 16 & 100 \\
\hline
\end{tabular}

Source: Research Primary Data in 2020

According to table 4, the interpretation of the characteristics of respondents based on the parity which is most respondents $10(62.5 \%)$ is multipara.

Table 5 Frequency Distribution Of Respondents Based On The Frequency Of Breastfeeding

\begin{tabular}{lll}
\hline Breast Feeding Freq. & Total & Percent $(\%)$ \\
\hline$>8$ times/day & 10 & 62,5 \\
$<8$ times/day & 6 & 37,5 \\
\hline Total & 16 & 100 \\
\hline
\end{tabular}

Source: Research Primary Data in 2020

According to table 5, the interpretation of the characteristics of the respondent based on the frequency of breastfeeding which is most respondents $10(62.5 \%)$ have the frequency of breastfeeding $<8$ times/day.

Table 6 Frequency Distribution Of Breast Milk Flow Before Being Administered The Combination Of Boiled Katuk And Kelor Leaves In Postpartum Mother

\begin{tabular}{ccc}
\hline $\begin{array}{c}\text { Breast Milk Flow before The } \\
\text { Treatment }\end{array}$ & Frequency & Percent (\%) \\
\hline Smooth & 3 & 18,8 \\
Not smooth & 13 & 81,3 \\
\hline
\end{tabular}


$\frac{\text { Total }}{\text { Source: Research Primary Data in } 2020}$

$16 \quad 100$

According to table 6, it can be interpreted that the flow of breast milk before administering the combination of boiled katuk leaves and kelor leaves which is most respondent 13 (81.3\%) have not smooth breast milk flow .

Table 7 Frequency Distribution Of Breast Milk Flow After Being Administered The Combination Of Boiled Katuk And Kelor Leaves In Postpartum Mother

\begin{tabular}{ccc}
\hline $\begin{array}{c}\text { Breast Milk Flow after The } \\
\text { Treatment }\end{array}$ & Frequency & Percent (\%) \\
\hline Smooth & 16 & 100 \\
Not smooth & 0 & 0 \\
\hline Total & 16 & 100 \\
\hline
\end{tabular}

Source: Research Primary Data in 2020

According to table 7, it can be interpreted that the flow of breast milk after being administered with the combination of boiled katuk and Kelor leaves which is all respondent $16(100.0 \%)$ have smooth breast milk flow.

Tabel 8 Analysis Of The Influence Of Breast Milk Flow Before And After Administering The Combination Of Boiled Katuk And Kelor Leaves Of Postpartum Mother

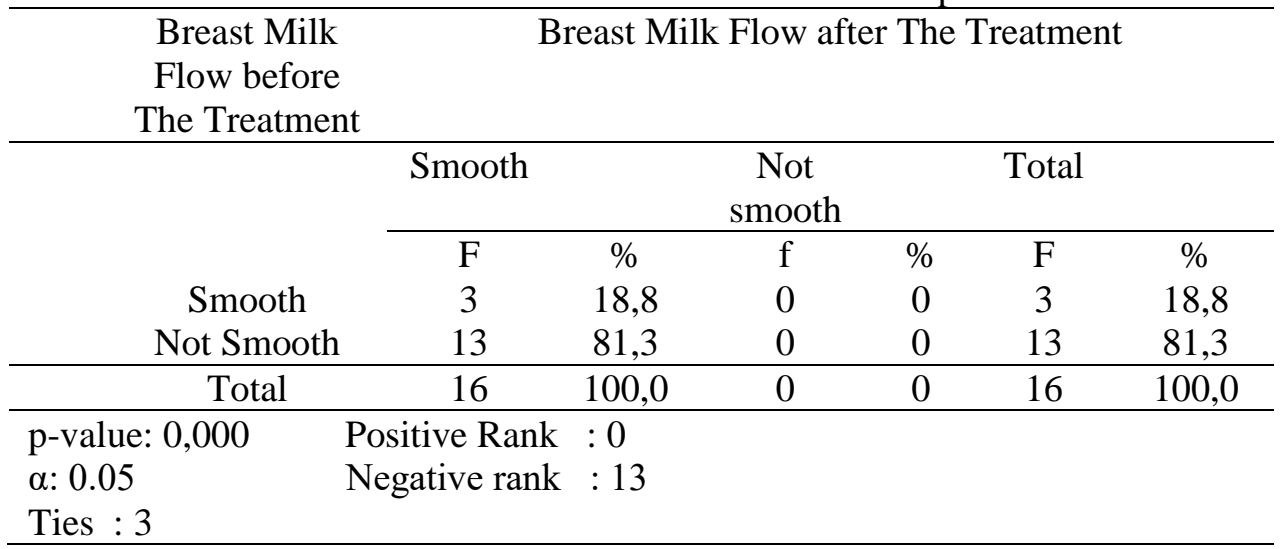

Source: Research Primary Data in 2020

Based on table 8, the results of analysis through Test Wilcoxon with SPSS in test statistics table obtained Z-3,606 value and obtained the value of $\rho$ value 0.000 where the value $\rho<0.05$. Because $P$ value of $<0.05$ then $\mathrm{H} 1$ accepted or $\mathrm{H} 0$ rejected which means there is the influence of the combination of the boiled Katuk leaf and Kelor leaves towards the flow of breast milk of postpartum mothers in the working area of Gampengrejo community health center in Kediri, 2020.

\section{DISCUSSION}

The lactation process begins with the growth and development of the mammary glands. Some hormones play a role in this process, especially hormones of estrogen, progesterone, and prolactin. Since early pregnancy occurs elevated levels of hormones that spur growth of ductus, formation of lobe and alveoli dairy glands, and the end of pregnancy occurs decreased levels of estrogen and progesterone hormones, as well as elevated levels of prolactin hormones in the mother's body. This rate is required by prolactin in order to spur breast milk formation by the mammary glands. Peripheral hormones, such as estrogen, thyroid hormone, vitamin $\mathrm{D}$, glucocorticoids are very potent modulators for the synthesis of prolactin and the compressed prolactin gene. Regulation of prolactin secretion by lactotroph cells seems to be largely controlled by the balance between Prolactin Releasing Factor (PRF) and Prolactin Inhibiting Factor (PIF) (Nurjanah, Kamariyah, \& Soleha, 2018)

Consumption of Sauropus leaf androgynus (L) Merr is suspected to contain a terpenoids compound that will work in lactotroph cells through the receptor-contained intracellular steroid hormones such as estrogen hormone work in spur synthesis and release of Prolactin by Hypofyse. In 
the theory of lactation, it is known that increasing the secretion of milk in lactation is closely related to increased levels of prolactin. Katuk leaf administering will stimulate the receptor.

Prolactin is present in the cells of Lactotroph as a producer of Prolactin. Such improvement occurs because with high dosing will cause a prolactin receptor stimulus in lactotroph cells to spur neurohormones that will stimulate the production of Prolactin Releasing Factor (PRF). The content of saponins and alkaloids found in the kelor leaves have functions that directly work on all smooth muscles. When smooth muscles are contraction, the breast milk will be expended as well as an increase in the number and diameter of the average alveoli comparable to the increase in breast milk resulting (Gunanegara, Suryawan, Sastrawinata, \& Surachman, 2010).

During the treatment of nursing mothers in healthy conditions (meals 3 times a day consist of rice, vegetables, fish, and milk every morning), then the mother will be spared from stress. Stress that occurs in nursing mothers will inhibit the work of prolactin Inhibitory Factor (PIF), so that prolactin is still well produced that will affect prolactin hormone of breastfeeding mothers. Psychological factors have long been known as the cause of breast milk flows barriers. Emotional and anxiety disorders can cause disturbances to the prolactin hormone, another factor affecting the prolactin hormone is the suction of the baby, the longer and the more frequent the baby breastfeeding the more breast milk is produced. The better the hormones prolactin and nutrients from nursing mothers who consume a combination of katuk leaves and kelor leaves (which are believed to have a good nutrient content) then the better the quality and quantity of milk consumed by infants.

The opinion of Kamariyah (2012), supports the reason above that the milk produced by a mother is varied, both quality and quantity. The factors that affect it are psychology, physiology, and Sociology. The psychology factor has long been castrating as the cause of breast milk flows barriers. Emotional and anxiety disorders can cause disturbances to "let down Reflex", which is a reflex that plays a role in milk water production from the mammary glands. The physiology factor affects the amount of milk, which is the effect of secreting and removing milk. The frequency and length of time for breastfeeding and the amount of stimulation in the nipple affects the amount of milk secreted and excreted from the mammary glands.

The formation of milk water in the mammary gland occurs inside the alveoli cell and then flowed into the lumen. The process involves taking a precursor from the blood that is further flowing into the cell. Already formed milk can be stored in the alveoli, duct, and sinus glands. The spending mechanism occurs after the mammary glands' gains stimulation. There are two types of stimuli that can lead to the production of milk, physical and psychic stimuli. Physical stimuli may include suction in the nipple or the manipulation of the mammary glands, while psychic stimuli can be stimuli associated with manipulation of the mammary gland, such as tears or craving for breastfeeding.

Physical or external stimuli in the form of baby suction in the nipple will pass through certain grooves that anatomically have the same pattern, both in animal and human beings. Oxytocin stimulates the contraction of the myopia cells surrounding the alveoli and the contraction causes the milk in the alveoli to be injected into the larger duct. Increased pressure will occur reflexively, allowing the milk to flow out through the nipple. The reflexes are called "let down reflexes. The baby who is breastfeeding will not get the milk directly, but should wait for approximately one and a half minutes before the milk flows out. Milk is not able to come out even if the milk is fully charged when without a "let down Reflex". Increased production of mains milk and good nutrition will increase the nutritional content of milk.

\section{CONCLUSION}

There is the influence of the combination of boiled Katuk leaf and Kelor leaves towards the breast milk flow of postpartum mother in the working area of Gampengrejo community health center Kediri in 2020. The medical staff is expected to provide information about the benefits of the combination of boiled katuk and kelor leaf for the postpartum mothers.

\section{REFERENCE}

Fahra, R. U. (2017). Status Paritas Dan Pekerjaan Ibu Terhadap Pengeluaran Asi Pada Ibu Menyusui 0-6 Bulan. NurseLine JOurnal, 2(2), 9.

Gunanegara, R., Suryawan, A., Sastrawinata, U., \& Surachman, T. (2010). Efektivitas Ekstrak Daun 
Katuk Dalam Produksi Air Susu Ibu Untuk Keberhasilan Menyusui. Jurnal Kedokteran Maranatha, 9(2), 104-117.

Kamariyah N, (2012) : Pengaruh ekstrak daun katuk terhadap peningkatan kadar hormone prolaktin tikus menyusui dan perkembangan sel neuralgia anak tikus. Tesis program pasca sarjana

Mutiara,T, 2011.Uji Efek Pelancar ASI Tepung Daun Kelor (Moringa Oilefera) Pada Tikus Putih Galur Wistar. Laporan Hasil Penelitian Disertasi Doktor. Malang

Mortel, M., \& Metha,SD, Systematic Review Of The Efficacy Of Herbal Galactogogues. Jurnal Human Lactation,29(2), 154-62

Nurjanah, S., Kamariyah, N., \& Soleha, U. (2018). PENGARUH KONSUMSI EKSTRAK DAUN SAUROPUS ANDROGYNUS (L) Meer (KATU) DENGAN PENINGKATAN HORMON PROLAKTIN IBU MENYUSUI DAN PERKEMBANGAN BAYI DI KELURAHAN WONOKROMO SURABAYA. Journal of Health Sciences, 10(1), 24-35. https://doi.org/10.33086/jhs.v10i1.154

profil kesehatan indonesia. (2018). Provil Kesehatan Indonesia 2018 (Vol. 1227). https://doi.org/10.1002/qi

Rahmanisa, S., \& Aulianova, T. (2016). Efektivitas Ekstraksi Alkaloid dan Sterol Daun Katuk (Sauropus androgynus) terhadap Produksi ASIBNPB. (2020). Bencana Indonesia 2020. https://bnpb.go.id/infografis/infografis-bencana-indonesia-2020. Jurnal Majority, 5(1), 117-121. Septadina, I. S., \& Murti, K. (2018). Effects of Moringa Leaf Extract (Moringaoleifera) in the Breastfeeding. Sriwijaya Journal of Medicine, 1(1), 74-79. https://doi.org/10.32539/sjm.v1i1.10 Wiji, 2013, ASI Dan Pedoman Ibu Menyusui. Yogyakarta; Nuha Medika

Yusrina, A., \& Devy, S. R. (2016). Influencing Factors of the Intentions Mothers Breastfeeding Exclusively in Kelurahan Magersari, Sidoarjo. Jurnal Promkes, 4(1), 11-21.

Zakaria, Hadju,V., As'ad, S., Bahar, B, Pengaruh Pemberian Ekstrak Daun Kelor Terhadap Kuantitas Dan Kualitas Air Susu Ibu Pada Ibu Menyusui Bayi 0-6 Bulan. Jurnal IKMI, 12(3). 